\title{
Lessons in Atrocity Prevention: A Closer Look at Guinea
}

\author{
Cristina G. Stefan * \\ Associate Professor of International Relations and Co-Director of The \\ European Centre for the Responsibility to Protect, University of Leeds, \\ Leeds, United Kingdom \\ C.Stefan@leeds.ac.uk
}

\begin{abstract}
This article identifies the most significant atrocity risk factors and their indicators in accordance with the UN Framework of Analysis for Atrocity Crimes and provides a taxonomy of measures, taken by a variety of external and internal stakeholders, in different combinations, which reduced the risk of atrocity crimes reoccurring after the 2009 stadium massacre in Conakry, Guinea. On the 28th of September 2009, 157 protesters were killed, at least 1200 were injured, and over 100 women were raped by security forces in a stadium in Conakry. The UN's Commission of Inquiry (COI) concluded that these crimes committed by the security forces amounted to crimes against humanity. The efforts to halt further violence and prevent the commission of crimes post-20o9 stadium massacre were varied and encompassed regional and international preventive diplomacy. The coordination of a coherent political strategy among international, regional and sub-regional actors in the Guinean context contributed towards the perceived success in preventing further atrocities in Guinea, post-20o9 massacre. Importantly, Guinea is not a typical example in terms of atrocity and conflict prevention, due to a unique regional and global dynamics that allowed for a rapid and rather coherent response to the September 2009 stadium massacre.
\end{abstract}

\section{Keywords}

Guinea - $\mathrm{R}_{2} \mathrm{P}$ - UN Commission of Inquiry - ECOWAS - African Union - security forces

* I am very grateful to Georgiana Epure for her excellent research assistance on the Guinea project for the United Nations. 
This article identifies the most significant atrocity risk factors and their indicators in accordance with the UN Framework of Analysis for Atrocity Crimes and provides a taxonomy of measures, taken by a variety of external and internal stakeholders, in different combinations, which reduced the risk of atrocity crimes reoccurring after the 2009 stadium massacre in Conakry, Guinea. On the 28th of September 2009, 157 protesters were killed, at least 1200 were injured, and over 100 women were raped by security forces in a stadium in Conakry. The UN's Commission of Inquiry (COI) concluded that these crimes committed by the security forces amounted to crimes against humanity. The Guinean judicial system, with its inadequate resources, high levels of corruption and dependence on the executive branch, has historically failed to hold accountable those responsible for human rights violations, especially members of the security forces. Guinea has been a heavily militarized society for decades. The military and other security forces wield a great deal of political and economic power, with security forces having been instrumentally used by authoritarian leaders since 1958 to supress political dissent, influence election outcomes and meddle into judicial matters. Impunity and a deep culture of unprofessionalism and poor discipline among security forces were the result of decades of in effective civilian control over security forces, high levels of corruption and poor governance.

The efforts to halt further violence and prevent the commission of crimes post-2009 stadium massacre were varied and encompassed regional and international preventive diplomacy, targeted sanctions and justice and security sector reforms, including measures aimed at combating impunity and strengthening accountability and the rule of law. The effectiveness of all these measures, taken together, was facilitated by the already existing diplomatic links and by the African-led institutional framework that was put in place after the 2008 coup. The African Union (AU) and the Economic Community of Western African States (ECOWAS) acted swiftly, by suspending Guinea's membership and establishing the International Contact Group on Guinea (ICG-G) As seen numerous times in the past, when regional and sub-regional actors speak with one voice on the African continent, the international community tends to listen to their messages faster. ${ }^{1}$ Despite regional and international actors' presence and efforts in Guinea after the 2008 coup, the measures that

1 Cristina G. Badescu and Linnea Bergholm. 'The African Union', in David Black and Paul D. Williams (eds.) The International Politics of Mass Atrocities: The Case of Darfur (London: Routledge, 2010), pp. 116-134. See also Cristina G. Stefan. 'On Non-Western Norm Shapers: Brazil and the Responsibility while Protecting', European Journal of International Security (2017) Vol. 2, Issue 1, pp. 88-110. 
were taken focused mainly on restoring constitutional order rather than on atrocity prevention, leaving many atrocity risk factors unaddressed.

The coordination of a coherent political strategy among international, regional and sub-regional actors in the Guinean context contributed towards the perceived success in preventing further atrocities in Guinea, post-20og massacre. The UN regional Office for West Africa (UNOWA) helped with the coordination on preventive diplomacy. The regional office provided logistical and technical support to the ECOWAS mediator and ensured policy consensus through the UNOWA Special Representative Said Djinnit's regular briefings to the International Contact Group and the UN Security Council, as well as through his contacts with leaders in the region. Appointing an UnOwA Special Representative with high authority in the region was another key element in the process.

The EU, AU and the US quickly imposed targeted economic sanctions in the form of travel bans and asset freezes on the National Council for Democracy and Development (CNDD) members, whereas regional actors (AU, EU and ECOWAS) imposed arms embargoes on Guinea to reduce the military's capacity given reports of increased arms flows in Guinea. Alongside the economic sanctions and arms embargo, another important resolution tool was the EU, US and France's withdrawal of their economic and military assistance to Guinea. Such targeted sanctions were a useful policy tool in bargaining and bringing relevant actors to the negotiation table.

Following the COI recommendations, the UN High Commissioner for Human Rights opened an office in Guinea in July 2010. The UN, through the Office of the UN High Commissioner for Human Rights (OHCHR), has been actively involved in institutional and legislative reforms of the security and justice sectors. The Country Office can be credited with coordinating various initiatives which ultimately prevented further atrocities from being committed in Guinea, especially surrounding election times. Following the COI Report, the International Criminal Court (ICC) opened a preliminary investigation in Guinea.

Importantly, Guinea is not a typical example in terms of atrocity and conflict prevention, given the unique regional and global dynamics that allowed for a rapid and rather coherent response to the September 2009 stadium massacre and the subsequent departure of Moussa Dadis Camara, the head of the military. The uniqueness of the Guinean context also relates to the fact that atrocities were not perpetrated by populations at large but by the Defence and Security Forces, which have a long history of gross human rights violations. This explains why the external assistance (both international, from the $\mathrm{UN}$, and regional and sub-regional) as well as the various prevention efforts focused heavily on institutional and legislative security and justice reforms. 
Since gaining independence from France in 1958, Guinea has had a history of autocratic and military political leadership coupled with serious human rights abuses and violence, often committed along ethnic lines. Against a background of unlawful transitions of power, endemic corruption and poor governance, ${ }^{2}$ increasing poverty, ${ }^{3}$ authoritarianism, hostility to political dissent, and an increasingly militarised society, ${ }^{4}$ protests and heavy reliance on ruling party militias and security forces to intimidate and repress opposition ${ }^{5}$ have become the norm within the country. This is in conjunction with widespread impunity for human rights abuses committed by those party militias and security forces. Following the death of President Conté in December 2008, a group of military officers, calling themselves the National Council for Democracy and Development (CNDD), launched a coup. Their Captain, Moussa Dadis Camara, declared himself President and pledged to hold elections in 2009. Meanwhile, he suspended the constitution, dismissed the National Assembly and continued Guinea's history of government crackdown on opposition.

In response to the 2008 unlawful change of power, regional, sub-regional and international actors coordinated efforts to restore constitutional order in Guinea. The African Union (AU) and the Economic Community of Western African States (ECOWAS) acted swiftly, suspending Guinea's membership and establishing the International Contact Group on Guinea (ICG-G). Together, they persuaded President Camara to agree to stand down from the presidency the following year and to allow for a transition to civilian rule. However, Camara eventually reneged on his promise and declared that he would run in the 2010 presidential elections. This led to an escalation in interethnic tensions and civilian protests, to which the ruling junta responded with violence. This violence reached its peak on 28 September 2009 when 157 protesters were killed, at least 1200 were injured, and over 100 women were raped by security

2 In 2006, Guinea ranked as the most corrupt country on the continent. Transparency International, 'Corruption Perceptions Index', Transparency International, 2006, available at https://www.transparency.org/en/cpi/20o6; Corinne Dufka, "We Have Lived in Darkness": A Human Rights Agenda for Guinea's New Government', Human Rights Watch (HRW), May 2011, available at https://www.hrw.org/sites/default/files/reports/guineao511webwcover_1.pdf, pp. 2, $5^{6-64 .}$

3 Countryeconomy.com, 'Guinea - Human Development Index - HDI', countryeconomy.com, n.d., available at https://countryeconomy.com/hdi/guinea.

4 Corinne Dufka, "We Have Lived in Darkness": A Human Rights Agenda for Guinea's New Government', $(H R W)$, pp. 49.

5 Ibid., pp. 1. 
forces in a stadium in Conakry. ${ }^{6}$ The UN's Commission of Inquiry (COI) found that the crimes committed by the security forces in the September 28 th massacre amounted to crimes against humanity. ${ }^{7}$ Notably, the 2009 massacre was just one of the many instances of atrocity crimes committed in Guinea. The country's long history of international human rights abuses (Risk Factor (RF) 2), the weakness of state structures ( $\mathrm{RF} 3$ ) - especially the lack of effective civilian control of security forces (RF 3.4) - and the inadequate and politicised mechanisms for accountability (RF 3.6) should have placed Guinea under the atrocity prevention radar earlier. Despite regional and international actors' presence and efforts in Guinea after the 2008 coup, the measures that were taken focused mainly on restoring constitutional order rather than on atrocity prevention, leaving many atrocity risk factors unaddressed.

\section{$2 \quad$ Risk Factors and Triggers}

This section utilises the 'Framework of Analysis for Atrocity Crimes' in the specific context of Guinea, in order to identify the most significant risk factors and triggers for atrocity crimes related to the 28 September 2009 stadium massacre.

Whilst Guinea has not experienced internal armed conflict or civil waralthough during different points in history it got caught up in regional conflicts - it has had a long history of political instability and has experienced numerous "situations that place a state under stress and generate an environment conducive to atrocity crimes" (Risk Factor ( $R F$ ) 1). As the assessment below shows, RF 1 was prevalent in Guinea for decades and manifested itself politically, economically and socially, including through tensions caused by "abrupt and irregular regime change and transfer of power" (RF 1.4), "autocratic regimes [and] severe political repression" (RF 1.6), "acute poverty, mass unemployment and deep horizontal inequalities" (R.F 1.9) and "mass protests against state authority and policies" (RF 1.10).

From 1958 until the 2010 elections, Guinea experienced three consecutive autocratic regimes that relied heavily on their militias and security forces to maintain power. All three regimes were characterized by severe political repression and ethno-patronage. ${ }^{8}$ Additionally, there were two unlawful

6 United Nations Security Council, Report of the International Commission on Inquiry Mandated to Establish the Facts and Circumstances of the Events of 28 September 2009 in Guinea, UN Doc S/2009/693, 18 December 2009, pp. 2.

7 Ibid., pp. 3 .

8 Nicole Gerber. 2013. 'Elections and Ethnicity in Guinea', Africa is a Country, 19 September 2013, available at http://africasacountry.com/2013/og/elections-and-ethnicity-in-guinea/ (accessed 
transitions of power through military coups in 1984 and 2008, and one failed coup in $1985 . .^{9}$ Notably, Guinea has a long history of intolerance for political opposition. Since independence, opposition and peaceful acts of defiance against the government have been continuously repressed by successive military and civilian administrations through violence, torture, abductions and killings ${ }^{10}$ over which impunity prevailed. ${ }^{11}$

Guinea's first president, Sékou Touré, was in power for four consecutive seven-year terms with no opposition, made possible by his ban on other political parties. After Touré's death in 1984, Colonel Lansana Conté seized power in a bloodless coup d'état. Following President Conté's death in December 2008, a group of young military officers (junta) who called themselves the National Council for Democracy and Development (CNDD), were led by Captain Moussa Dadis Camara in launching another coup. Camara declared himself President and formed a government primarily composed of military officials. He pledged to eradicate corruption, improve the human rights situation in the country, and hold elections in 2009. Soon after, he suspended the constitution and dismissed the National Assembly. Camara's government's crackdown on pro-democracy protesters reached its peak on 28th September 2009 when 157 protesters were killed, at least 1200 were injured, and over 100 women were raped by security forces in a stadium in Conakry. ${ }^{12}$

In addition to autocratic regimes and unlawful transfers of power, instability in Guinea was also caused by economic factors including acute poverty, mass unemployment, deep horizontal inequalities (RF 1.9) and social tensions linked to mass protests against state authorities (RF 1.10). For decades, Guinea has been a bottom-of-the-list country in the Human Development Index, with poverty and wellbeing indicators increasingly deteriorating. ${ }^{13}$ According to Transparency International, in 2006 Guinea was ranked as the most corrupt

20 March 2018); IRIN News, 'Avoiding ethnically-driven elections', The New Humanitarian,

6 December 2011, available at http://www.irinnews.org/report/94405/guinea-avoidingethnically-driven-elections (accessed 20 March 2018).

9 The Daily Telegraph, "Lansana Conté", The Daily Telegraph, 30 December 2008, available at https:/www.telegraph.co.uk/news/obituaries/4031475/Lansana-Cont.html.

Alieu Darboe, 'Guinea: 1958-Present: Summary of events related to the use or impact of civil resistance', International Center on Nonviolent Conflict, October 2010, available at https:// www.nonviolent-conflict.org/wp-content/uploads/2016/o2/guineasummary.pdf, pp. 2 Corinne Dufka, "We Have Lived in Darkness": A Human Rights Agenda for Guinea's New Government', (HRW), pp. 11.

United Nations Security Council, Report of the International Commission on Inquiry Mandated to Establish the Facts and Circumstances of the Events of 28 September 2009 in Guinea, pp. 2.

Countryeconomy.com, 'Guinea - Human Development Index - HDI', countryeconomy.com. 
country in Africa. ${ }^{14}$ Mass protests in 2006 and 2007 were a response to inequalities and poor governance and were met with violent suppression by Guinea's security forces. Driven by economic grievances and eager for reforms, nationwide general strikes began in June 2006, effectively paralyzing the country. The Guinean security forces responded with excessive use of force, claiming at least 13 lives in 2006. ${ }^{15}$

Unlike the 2006 general strike, the other mass strike in 2007 was more political in nature, led by trade union federations. Demonstrators protested not only against the high cost of living, but also against poor governance and lack of democracy under the regime of President General Lansana Conté. They asked the President to sack his cabinet, to appoint a new prime minister with power to form a consensus government, and to prosecute individuals charged with embezzlement of public funds. ${ }^{16}$ The security forces, including the gendarmerie, the police, and the presidential guard, also known as the "Red Berets", were responsible for the killing of at least 137 persons and for injuring more than 1700 demonstrators. ${ }^{17}$ The 2007 strike was one of the most violent demonstration since Guinea's independence, ${ }^{18}$ and had similar numbers of casualties to those witnessed in 2009 .

Guinea has had a decades-long record of serious violations of international human rights, and in particular it has developed a pattern of extreme use of violence by security forces to repress dissent. Successive governments have consistently used the military to remain in power. Such crimes have not been prevented, punished or adequately addressed, creating a risk of further violations. The serious record of violations, coupled with a culture of impunity, has led to widespread mistrust in state institutions ( $\mathrm{RF}$ 2.8). ${ }^{19}$ The Guinean

14 Transparency International, 'Corruption Perceptions Index', Transparency International; Corrine Dufka, “We Have Lived in Darkness”: A Human Rights Agenda for Guinea's New Government', $H R W$, pp. 2, 57-64.

15 HRw, "The Perverse Side of Things": Torture, Inadequate Detention Conditions, and Excessive Use of Force by Guinean Security Forces', HRW, August 20o6, available at https:// www.hrw.org/reports/2006/guineao8o6/guineao8o6webwcover.pdf, pp. 19-25; HRW, 'Dying for Change: Brutality and Repression by Guinean Security Forces in Response to a Nationwide Strike', HRW, April 2007, available at https://www.hrw.org/reports/2007/ guinea0407/guineao407webwcover.pdf, pp.13-14.

16 HRW, 'Dying for Change: Brutality and Repression by Guinean Security Forces in Response to a Nationwide Strike', $H R W$, pp. 14.

17 Ibid., pp. 3, 65 .

18 Ibid.

19 See Elise Keppler, 'Waiting for Justice: Accountability before Guinea's Courts for the September 28, 2009 Stadium Massacre, Rapes, and Other Abuses', HRW, December 2012, available at https://www.hrw.org/sites/default/files/reports/guinea1o12forUpload_o_o.pdf. 
judicial system, with its inadequate resources, high levels of corruption ${ }^{20}$ and dependence on the executive branch, has historically failed to hold accountable those responsible for human rights violations, especially members of the security forces. ${ }^{21}$ As the assessment below shows, RF 2 and 3 have been deeply present in Guinea for decades, manifesting especially through "past atrocity crimes that have not been adequately addressed through individual criminal accountability [..] and reconciliation processes, as well as comprehensive reform measures in the security and judicial sectors". ${ }^{22}$ As noted in the UN Framework of Analysis for Atrocity Crimes, the likelihood of a society to resort again to violence as a form of addressing problems increases.

Guinea lacks an independent and impartial judiciary. The judicial system has been the subject of politicization (RF 3.3) since the country's independence, beginning with Sekou Touré's regime, which was heavily characterized by political crimes for which there have been no trials. This continued with Lasana Conté's regime that failed to bring to justice any security forces members involved in killings and other grave human rights violations, including those committed during the 2006 and 2007 strikes. Moussa Dadis Camara's short regime further undermined and side-lined the national judicial system due to Camara's ruling by decree, interference with the judicial branch's independence ${ }^{23}$ and CNDD's failure to investigate crimes and abuses at the hands of its soldiers. ${ }^{24}$

Despite the establishment by the National Assembly of the Independent National Commission of Inquiry into the 2007 strike-related violence in May 2007, the Commission did not benefit from government funding and support. ${ }^{25}$ This made its work impossible. The National Commission of Inquiry did not conduct any investigations during its short mandate which expired in

20 Corrine Dufka, “We Have Lived in Darkness”: A Human Rights Agenda for Guinea's New Government', $H R W$, pp. 57-64.

21 Corrine Dufka et al, 'Bloody Monday: The September 28 Massacre and Rapes by Security Forces in Guinea', $H R W$, available at https://www.hrw.org/sites/default/files/reports/ guinea12ogwebwcover_o.pdf, pp. 96.

22 United Nations Office on Genocide Prevention and the Responsibility to Protect, Framework of Analysis for Atrocity Crimes: A Tool for Prevention, (New York: United Nations, 2014), pp. 11.

23 Corrine Dufka, "We Have Lived in Darkness": A Human Rights Agenda for Guinea's New Government', $H R W$, pp. 41.

24 Ibid., pp. 16.

25 The lack of support is explained by the fact that the 2007 protests were opposing the President at the time (Colonel Lansana Conte) and his government. The security forces acted to stop the protests in Conte's name. 
January 2009. ${ }^{26}$ One civil society representative in Guinea said the National Commission of Inquiry was there cosmetically to demonstrate progress in investigating the killings to external actors. More importantly, the Commission was designed to pressure senior officials and certain factions of the military to conform to Conté's government orders, or else face the regime exposing details of the killings. ${ }^{27}$

After the CNDD's coup in 2008, the military continued to interfere with the judiciary and the new government attempted to establish and run a parallel informal judicial system from the Alpha Yaya Diallo military camp. ${ }^{28}$ The Guinean judicial system became even weaker. As the UN Special Adviser to the Secretary-General on the Prevention of Genocide declared after a mission visit to Guinea in March 2010:

Impunity is the norm; perpetrators of past violence and human rights violations have gone unpunished, including those responsible for massive human rights violations committed during the previous regimes of Sékou Touré and Lansana Conté. ${ }^{29}$

As one civil society leader in Guinea mentioned, news from Guinea regarding genuine investigations and justice for the past gross human rights violations would mean that the military was no longer in power. ${ }^{30}$

Political challenges apart, technical institutional barriers also posed key challenges in making investigations and prosecutions fair, impartial, independent and effective. ${ }^{31}$ Guinea lacked a witness protection program and did not provide adequate security of judicial personnel. Notably, the death penalty was legal, and torture and crimes against humanity were not criminalized under Guinean law (which meant perpetrators risked being prosecuted for ordinary crimes). Furthermore, domestic law did not include command responsibility as a mode of liability, as required by the Rome Statute. ${ }^{32}$

26 Corrine Dufka, “We Have Lived in Darkness": A Human Rights Agenda for Guinea's New Government', $H R W$, pp. 3 o.

27 Interview with a civil society leader in Guinea.

28 Corrine Dufka et al, 'Bloody Monday: The September 28 Massacre and Rapes by Security Forces in Guinea', $H R W$, pp. 96.

29 The New Humanitarian, 'Guinea: Obstacles, omens and opportunities', reliefweb, 21 March 2011, available at https://reliefweb.int/report/guinea/guinea-obstacles-omens-and-opportunities.

30 Interview with the author.

$31 \quad$ Corrine Dufka, “We Have Lived in Darkness": A Human Rights Agenda for Guinea's New Government', $H R W$, pp. 25-30.

$3^{2}$ Elise Keppler, 'Waiting for Justice: Accountability before Guinea's Courts for the September 28, 2009 Stadium Massacre, Rapes, and Other Abuses', HRW, pp. 34-44; Corrine Dufka, “We 
The amount of financial resources allocated to the judiciary reflected Guinea's lack of priority for criminal accountability and justice for victims of gross human rights violations. For instance in 2007, national budgetary allocations for the judiciary amounted to 0.23 percent and in 2008 to 0.37 percent. ${ }^{33}$ Moreover, according to a Human Rights Watch report and a study of the judiciary by the European Union, the disbursement rate to the Ministry of Justice further reduced the judiciary's operational capacity as there were jurisdictions that went years with no budgetary funds. ${ }^{34}$

Given the rapid expansion of the Guinean army in the aftermath of a series of attacks coming from Sierra Leonean rebels and Liberian government forces, the size of the army increased four times over the course of a decade, between 2001 and 2011. ${ }^{35}$ With the rapid growth of the army, newly recruited soldiers skipped the established recruitment procedures and adequate training on human rights. ${ }^{36}$ This added yet another layer to those risk factors pertaining to security forces' engagement in human rights abuses.

For decades, Guinea has been a heavily militarized society. The military and other security forces wield a great deal of political and economic power. Security forces have been instrumentally used by authoritarian leaders virtually under all regimes since 1958 - for their political ends to supress political dissent, to influence election outcomes and meddle into judicial matters. As a Human Rights Report put it, the "military was everywhere", especially after the $2008 \mathrm{CNDD}$ coup. ${ }^{37}$ In return for their political loyalty, military personnel were given higher military and political offices or economic power. ${ }^{38}$ The role of the military in society has also been highlighted in the $2009 \mathrm{UN}$ International Commission of Inquiry report:

The Guinean people have long been subject to coups d'états accompanied by grave and repeated violations of human rights. This situation is made possible by the existence of a very particular kind of army in Guinea and the repeated violations of human rights is a consequence of the

Have Lived in Darkness": A Human Rights Agenda for Guinea's New Government', $H R W$, pp. 49; Mohamed Saliou Camara, 'From Military Politization to Militarization of Power in Guinea-Conakry', Journal of Political \& Military Sociology, vol. 28, issue 2, 20oo, pp. 311-326. Corrine Dufka, "We Have Lived in Darkness": A Human Rights Agenda for Guinea's New Government', $H R W$, pp. 35 .

34 Ibid.

35 Ibid., pp. 51.

36 Ibid., pp. 50.

37 Ibid., pp. 49.

$38 \quad$ Ibid. 
impunity that is virtually institutionalized. These two phenomena-an atypical army and institutionalized impunity — are the real and profound weaknesses of the political system in Guinea. ${ }^{39}$

Impunity and a deep culture of unprofessionalism and poor discipline among security forces were the result of decades of no effective civilian control over security forces (RF 3.3) and high levels of corruption and poor governance (RF 3.5). The lack of political will to ensure discipline and accountability for abuses committed by security forces has resulted in Guineans' deep mistrust in state institutions and security forces (RF 2.8). ${ }^{40}$ Furthermore, the lack of civilian oversight over the security forces meant that for many years - including under the Conté and Camara regimes - the military budget suffered from an acute lack of transparency. There was no monitoring of military spending from the Parliament or the Ministry of Finance, no audits or record keeping, which all translated into high-level acts of corruption, and no adherence to legal procurement procedures. ${ }^{41}$

Whilst security forces had substantial human and financial resources, as well as political support from the state ( $\mathrm{RF} 5.7$ ), this did not automatically translate into security forces being prone to committing atrocity crimes. The capacity of the security forces to commit gross human rights violations in order to protect the regime has been developed incrementally for decades. The Guinean security forces past record of human rights abuses and their political instrumentalization to supress protests (as in 2006 and 2007), as well as the rapid growth of the army in 2009 should have alarmed international and regional actors before the 28 th September massacre.

The capacity of the security forces increased as a result of the rapid expansion of the army in the aftermath of a series of attacks on Guinea from Sierra Leonean rebels and Liberian government forces. For instance, between 2001 and 2011, the size of the Guinean army increased four times, reaching the size of Uganda's army - a much larger country, and being double in size compared to neighbouring Senegal, which has been fighting a separatist movement for two decades. ${ }^{42}$ During Contés last years of rule, the military was allocated impressive financial resources (RF 5.1): over $12 \%$ of the annual national budget

39 United Nations Security Council, Report of the International Commission on Inquiry Mandated to Establish the Facts and Circumstances of the Events of 28 September 2009 in Guinea, para. 259 .

40 Corrine Dufka, “We Have Lived in Darkness": A Human Rights Agenda for Guinea's New Government', $H R W$, pp. 52 .

41 Ibid., pp. 59-6o.

$42 \quad$ Ibid., pp. 51. 
in 2007 and 2008. The military budget doubled in 2009 under the Camara regime and spiked to $33.5 \%$ in $2010 .{ }^{43}$ Considering Guinean leaders' history of heavy reliance on security forces to maintain their power, the continuous increase of the army and its resource allocation (in a country that has had an otherwise peaceful co-existence with its neighbouring countries after the first years of the 21st century) could have been a solid indicator that autocratic leaders would make use of it when their power was challenged, as was the case in 2006, 2007 and 2009.

Atrocity crimes triggers for the 2009 stadium massacre can be associated with two distinct phases:

(1) The 2008 coup d'etat, when Camara's forces took power hours after Conte's death, suspended the constitution and dismissed the National Assembly.

(2) The large pro-democracy protest on 28 September 2009. At least 157 people were killed, at least 109 women and girls were raped and subjected to other forms of sexual violence, and over 1,ooo people were injured as a result of the events in the stadium and the surrounding areas, which amounted to atrocities perpetrated by the Defence and Security Forces (DSF).

Both Presidential elections, in 2010 and 2015, triggered clashes between protesters and security forces, both prior and in the aftermath of releasing the election results. Similarly, discussions related to scheduling legislative elections - postponed multiple times - have seen several people killed in clashes between security forces and opposition. In fact, some of the most serious clashes peaked and deaths occurred in several key months, either before or after elections, or in relation to protests over the timetable of elections. These included: October 2010 (ahead of run-off presidential elections), November 2010 (after Alpha Conté became President for the first time), May 2012, March 2013, April 2015, and August 2017.

\section{$3 \quad$ Evaluating Prevention Measures}

In response to the 2009 massacre, regional (AU, EU, ECOWAS) and international actors (UN) pressured the CNDD and its supporters to refrain from further violence, to restore constitutional order, and to return the government to civilian rule. The measures were varied and encompassed preventive diplomacy,

43 Corrine Dufka, “We Have Lived in Darkness": A Human Rights Agenda for Guinea's New Government', $H R W$, pp. 51. 
targeted sanctions, justice and security sector reforms, and included measures aimed at combating impunity and strengthening accountability and the rule of law. The effectiveness of all these measures, taken together, was facilitated by the already existing diplomatic links and by the international and regional institutional framework that was put in place after the 2008 coup. However, the focus of these measures was on crisis diplomacy and mediation for restoring constitutional order in Guinea, rather than atrocity prevention. Notably, an analysis of preventive measure following the 2009 massacre would be incomplete without considering the regional and international responses to the 2008 coup.

Strong condemnations of the September 28th 2009 violence came quickly from the $\mathrm{UN}^{44}$ and the African Union, which had previously suspended Guinea's membership following the coup in $2008 .{ }^{45}$ Both the UN and AU called for those responsible for the violence to be held accountable. ${ }^{46}$ EcowAs, the UN Security Council, the UN Secretary-General, and individual states such as France ${ }^{47}$ and the US, ${ }^{48}$ issued condemnation statements which criticised Guinea's deviation from norms such as constitutional transition of power and the responsibility to protect populations from mass atrocities. The regional and international response to the 28 September massacre combined a series of encouragement, pressure and support actions, providing a swift diplomatic response.

In the aftermath of the 2008 coup, the international community and especially the key regional actors focused their efforts on returning Guinea to civilian rule and constitutional order. EcowAs played a crucial role in leading this process after the coup and continued to work with Guinean authorities after the 2009 massacre. EcowAS quickly appointed Blaise Compaoré, the President of Burkina Faso, to act as mediator between the CNDD and civil society. Notably,

44 United Nations Secretary-General, 'Statement attributable to the Spokesperson for the Secretary-General on Guinea, United Nations Secretary-General, 28 September 2009, available at https://www.un.org/sg/en/content/sg/statement/20o9-o9-28/statement-attributablespokesperson-secretary-general-guinea-scroll.

45 Associated Press, "Guinea: Sanctions From African Union", The New York Times, 30 December 2008, available at http://www.nytimes.com/2008/12/3o/world/africa/3obriefsSANCTIONSFRO_BRF.html.

46 African Union, 'Guinea: Statement of the African Union on Events in Conakry', allAfrica, 29 September 2009, available at https://allafrica.com/stories/200909290925.html.

47 AgenceFrance-Presse, “Guinée:'Onnepeut plustravailler avec Dadis Camara', selon Kouchner”, jeuneafrique, 4 October 2009, available at https:/www.jeuneafrique.com/depeches/103647/ politique/guinee-on-ne-peut-plus-travailler-avec-dadis-camara-selon-kouchner/.

48 US Department of State, 'Remarks With Pakistani Foreign Minister Shah Mehmood Qureshi After Their Meeting' US Department of State, 6 October 2009, available at https://20o9-2017. state.gov/secretary/20092013clinton/rm/2009a/10/130314.htm. 
Blaise Compaoré was also the person EcowAs put forward as mediator in the Ivory Coast crisis in 2010-2011. ECOWAS appeared to be leading the efforts in mediation and atrocity prevention in Guinea. And yet, according to one civil society leader in Guinea, it was France that led these processes from behind, with Blaise Compaoré being "France's man".99 Following President Camara's incapacitation, having been shot by his aide-de-camp in a dispute about who was responsible for the 2009 stadium massacre, and his evacuation to Morocco for medical assistance and then to Burkina Faso, Blaise Compaoré facilitated a hand-over of power to Camara's Defense Minister, Gen. Sékouba Konaté, who agreed to take over as interim president. ${ }^{50}$ Under Ec CowAS supervision, Camara and Konaté agreed to sign an agreement in Ouagadougou on 15 January 2010. Known as the Ougadougou Peace Agreement, the agreement became the main quasi-legal document that would shape Guinea's the transition to a democratically elected government. ${ }^{51}$

ECOWAS (and particularly one of its members, Burkina Faso) was generally regarded as a successful actor in averting further violence or escalation of conflict. ECOWAS's early intervention in Guinea is the perfect illustration of its strength in providing a diplomatic response to coups and other unconstitutional attempts to grasp power, but not in military intervention, as its intervention in Cote d'Ivoire clearly demonstrates. ${ }^{52}$

It appears that the coordination of a coherent political strategy among international, regional and sub-regional actors in the Guinean context contributed towards the perceived success in preventing further atrocities in Guinea, post2009 massacre. The UN regional Office for West Africa (UNOWA) helped with the coordination on preventive diplomacy. The regional office provided logistical and technical support to the EcowAs mediator and ensured policy consensus through the UnOwA Special Representative Said Djinnit's regular briefings to the International Contact Group and the UN Security Council, as well as through his contacts with leaders in the region. Appointing an UnOwA Special Representative with high authority in the region, as was the case with Said

49 According to a civil society representative interviewed for this project.

50 The Carter Center, 'Observing the 2010 Presidential Elections in Guinea: Final Report', The Carter Center, 19 November 2010, available at https://www.cartercenter.org/resources/pdfs/ news/peace_publications/election_reports/guinea-2010-finalreport.pdf.

UN Peacemaker, 'Ouagadougou Joint Declaration', UN Peacemaker, 15 January 2010, available at: https://peacemaker.un.org/sites/peacemaker.un.org/files/GN_100115_ DeclarationConjointeOuagadougou.pdf.

$5^{2}$ Fabienne Hara, 'Preventive Diplomacy in Africa: Adapting to New Realities', International Peace Institute, 31 December 2011, available at https://www.crisisgroup.org/africa/ preventive-diplomacy-africa-adapting-new-realities. 
Djinnit, the Secretary-General's Special Representative and head of UNOwA, appears therefore to have been a crucial an element in the process.

Importantly, Guinea is not a typical example in terms of atrocity and conflict prevention, given the unique regional and global dynamics that allowed for a rapid and rather coherent response to the September 2009 stadium massacre and the subsequent departure of Moussa Dadis Camara. Camara's aidede-camp's attempt to assassinate him also hastened the transition to civilian rule. President Compaore and his appointment of Sekouba Konate as the head of the transitional government, who then in turn agreed to organize elections, facilitated this context further and proved significant. Willing regional partners together with the US and France's engagement triggered the creation of the UN Commission of Inquiry following the massacre. EcowAs's belief that the Camara regime would not provide stability to Guinea was shared by other external players such as Russia and China, with serious investments - and therefore interests - in Guinea. ${ }^{53}$

The EU, ${ }^{54} \mathrm{AU}$ and the US quickly imposed targeted economic sanctions in the form of travel bans and asset freezes on CNDD members. ${ }^{55}$ Regional actors - the AU, EU ${ }^{56}$ and Ecowas (under the Ecowas Convention on Small Arms and Light Weapons) ${ }^{57}$ - imposed arms embargoes on Guinea to reduce the military's capacity given reports of increased arms flows in Guinea. Alongside the economic sanctions and arms embargo, another important resolution tool was the EU, ${ }^{58}$ US $^{59}$ and France's withdrawal of their economic and military assistance to Guinea.

\section{Ibid.}

54 The Council of the Eurpean Union, 'Council Common Position 2009/788/CFSP of 27 October 20o9', Official Journal of the European Union, 28 October 2009, available at http://eur-lex.europa.eu/LexUriServ/LexUriServ.do?uri=OJ:L:20og:281:00o7:oo11:EN:PDF.

55 Reuters Staff, "African Union Imposes Sanctions on Guinea Junta", Reuters, 29 October 2009, available at https://www.reuters.com/article/idUSLT440627.

56 The Council of the Eurpean Union. 2010. 'Council Decision 2010/638/CFSP of 25 October 2010 concerning restrictive measures against the Republic of Guinea', Official Journal of the European Union, available at http://eur-lex.europa.eu/legal-content/EN/TXT/PDF/?uri=CEL EX:32010Do638\&from=EN.

57 ECOWAS, 'Press Release: ECOWAS Leaders Call for Suspension of Legislative Elections in Niger, Want New Transition Authority in Guinea', ECOWAS, 17 October 2009, available at https://www.sipri.org/sites/default/files/2016-03/20091017_ECOWAS_Guinea-armsembargo.pdf.

58 The Council of the European Union, 'Council Common Position 2009/788/CFSP of 27 October 20o9', Official Journal of the European Union, available at http://eur-lex.europa. eu/LexUriServ/LexUriServ.do?uri=OJ:L:2009:281:0007:0o11:EN:PDF.

59 US Department of State, 'Guinea: Travel Restrictions,' US Department of State, 29 October 2009, available at http://www.state.gov/r/pa/prs/ps/20og/oct/131047.htm (accessed 24 November 2009). 
Whilst these targeted economic sanctions were not the solution to the crisis and were not meant to address the underlying causes of human rights abuses in Guinea, they were a useful policy tool in bargaining and bringing relevant actors to the negotiation table. ${ }^{60}$ Targeted sanctions have three main different purposes: to signal, constrain and/or coerce.$^{61}$ The variety of sanctions that were used since the 2008 coup, including AU's and EcOWAS' suspension of Guinea's membership from the organisation, ${ }^{62}$ and the ICC's preliminary investigation in October $2009,{ }^{63}$ triggered important effects. The sanctions, membership suspension and the ICC's opening of the preliminary examination stigmatised the junta and CNDD members, signalled Guinea's deviation from norms of human protection and isolated the country from its regional community. Notably, they created costs and interfered in the decision-making calculus of the targeted junta members, coercing them to come to the negotiation table.

After Camara's move to Morocco for medical care and interim President Sekouba Konaté taking over, there was a shift in the degree of openness for negotiation and preventive diplomacy ${ }^{64}$ Although the economic sanctions were not imposed by the UN Security Council and thus were not universal in nature, they were nonetheless effective as junta members, and especially Konaté, were extremely keen to be removed from the sanctions list, which made them more open to collaborations. Finally, the EU's arms embargo ${ }^{65}$ and its withdrawal of economic and military assistance constrained the military's capacity for mass atrocities.

6o Thomas Biersteker, 'The Art of Sanctions', Brown Journals of World Affairs, vol. 21, issue 2, 2013, pp. 17 .

61 Francesco Giumelli, Coercing, Constraining and Signaling: Explaining and Understanding International Sanctions after the End of Cold War (Colchester, UK: ECPR Press).

62 Felix Onuah, "Ecowas Suspends Guinea Until Democracy Restored", Reuters, 10 January 2009, available at https://af.reuters.com/article/topNews/idAFJOE509o8M20ogono.

63 Office of the Prosecutor, 'ICC Prosecutor confirms situation in Guinea under examination', International Criminal Court, 14 October 2009, available at https:/www.icc-cpi.int/Pages/ item.aspx?name=otp-stat-guinea-o9-10-14.

64 According to one civil society analyst from Conakry interviewed for this research project, it was rather clear that Alpha Conde, the winner of the 2010 presidential election and the current president (an ethnic Mandinga) was to become president; General Konate was a Mandinga too.

65 Council of the European Union, 'Council Decision (CFSP) 2017/1934', Official Journal of the European Union, 23 October 2017, available at http://eur-lex.europa.eu/legal-content/EN/ TXT/PDF/?uri=CELEX:32017D1934\&from=EN. 
Following the 2009 stadium massacre, the international community was quick to employ accountability measures as tools to deter further violence. ${ }^{66}$ Two days after the massacre, the онCHR called for an independent inquiry. ${ }^{67}$ The following month, following ECOWAS and the AU's proposal of an international commission of inquiry, the UN Secretary-General announced the establishment of a UN Commission of Inquiry (COI), signalling that the international community is watching the developments of the crisis in Guinea and that perpetrators will be held accountable. ${ }^{68}$ In December 2009, the International Commission of Inquiry found that crimes against humanity took place, planned and organized by senior officials in the security forces.

Following the COI recommendations, the UN High Commissioner for Human Rights opened an office in Guinea in July 2010, to "support the Government's efforts to protect human rights, to fight against impunity, which has bedevilled Guinea for decades, and to empower the Guinean people in the realization of all their rights, including economic, social and cultural rights".69 Since the opening of the Country Office, the UN, through the Office of the High Commissioner for Human Rights (OHCHR), has been actively involved in institutional and legislative reforms of the security and justice sectors. The Country Office was instrumental in this sense, and can be credited with coordinating various initiatives which ultimately prevented further atrocities from being committed, especially surrounding election times (see below).

The International Criminal Court (ICC) opened a preliminary investigation in Guinea on 14 October 2009 - Guinea has been a state party to the Rome Statute since $2003 \cdot{ }^{70}$ The ICC preliminary investigations and referrals in the

66 Naomi Kikoler, 'Guinea: An Overlooked Case of the Responsibility to Prevent in Practice', in Jennifer Welsh and Serena Sharma (eds.) The Responsibility to Prevent: Overcoming the Challenges of Atrocity Prevention (Oxford: Oxford Scholarship Online, 2015), pp. 311.

67 онсHR, 'ОНСHR in Guinea (2010-2011)', ОHCHR, n.d., available at http://www.ohchr.org/ EN/Countries/AfricaRegion/Pages/GNSummary20102011.aspx.

68 Office of the UN Secretary-General, 'Secretary-General Announces Members of Guinea Commission of Inquiry to Investigate Events of 28 September', Department of Public Information, 30 October 2009, available at https://www.un.org/press/en/2009/sgsm12581. doc.htm.

69 UN News, "New UN Human Rights Office to open in Guinea to help prevent abuses", United Nations, 5 May 2010, available at http://www.un.org/apps/news/story.asp?NewsID=346o6\&C $\mathrm{r}=$ conakry\&Cri.

70 Office of the Prosecutor, 'ICC Prosecutor confirms situation in Guinea under examination', International Criminal Court. 
past were intended to deter the commission of future crimes and perpetrators from engaging and planning atrocities. ${ }^{71}$ Shortly after the announcement, Guinea's foreign minister met with ICC officials and assured them that Guinea has both the ability and the willingness to deliver justice for the victims of the 2009 massacre. ${ }^{72}$ The ICC Prosecutor visited Guinea three times in 2010 and in March 2011 to assess the progress of national authorities in investigating the massacre. ${ }^{73}$ October 2018 marked the Office of the Prosecutor (отP)'s sixteenth mission to Conakry, to get updates on the status of national proceedings and assess "the prospect of organizing a trial within a reasonable time frame". ${ }^{74}$ The ICC has been vital in encouraging and pressing the new government to keep accountability on its agenda, and in supporting national accountability processes with relevant expertise. In 2012, the Guinean government accepted the technical expertise of the UN Office of the Special Representative of the Secretary-General on Sexual Violence in Conflict especially in regard to accountability for sexual violence committed by perpetrators on 28 September 2009. ${ }^{75}$ Despite the international assistance, progress regarding accountability and justice has been extremely slow. More than ten years after opening its preliminary examination in October 2009, the ICC has not started an investigation in Guinea. Under the complementarity principle, the ICC cannot open an investigation if the state is investigating and bringing those responsible to account domestically. As one Guinean civil society representative put it, "the Government is smart; they know that the Court cannot intervene if they look like they are working on delivering justice". ${ }^{6}$

71 "See, for example, Cristina G. Stefan and Kirsten Fisher, "The Ethics of International Criminal 'Lawfare"' International Criminal Law Review (2016) Vol. 16, Issue 2, pp. 237-257.

72 The Office of the Prosecutor, 'Guinea Minister visits the ICC - Prosecutor Requests Information on National Investigations into 28 September Violence', International Criminal Court, 21 October 2009, available at Guinea Minister visits the ICC - Prosecutor Requests Information on National Investigations into 28 September Violence (icc-cpi.int).

73 Corrine Dufka, “We Have Lived in Darkness": A Human Rights Agenda for Guinea's New Government', $H R W$, pp. 22; Seattle Times Staff, "World court 'satisfied' with Guinea massacre probe", The Seattle Times, 21 May 2010, available at World court 'satisfied' with Guinea massacre probe $\mid$ The Seattle Times.

74 The Office of the Prosecutor, 'Report on Preliminary Examination Activities 2018', International Criminal Court, 5 December 2018, available at https://www.icc-cpi.int/ itemsDocuments/181205-rep-otp-PE-ENG.pdf, pp. 47.

75 Office of the Special Representative of the Secretary General on Sexual Violence in Conflict. 'Annual Report 2011: Team of Experts: Rule of Law/Sexual Violence in Conflicts', Stop Rape Now, 2011, available at http://www.stoprapenow.org/uploads/advocacyresources/1334926o44. pdf, pp. 17 .

76 Author's interview. 
Indeed, three Guinean investigative judges ("panel of judges") were appointed to conduct a national investigation into the 28 September 2009 events, which was completed in December 2017. While national proceedings were ongoing, the ICC's Office admissibility assessment focused "on whether the national authorities are willing and able to conduct genuine investigations and prosecutions, and in particular whether proceedings are conducted with the intent to bring to justice the alleged perpetrators within a reasonable time frame."77 In its latest report, the ICC assessed that the Guinean authorities made "progress in their efforts to prosecute those most responsible for the [Conakry stadium] crimes... [but] key aspects for the holding of the trial... are still pending, including the finalisation of the budget, the setting-up of a security plan for all actors involved..., the participation and protection scheme for victims and witnesses, ... and the identification of a suitable time frame."78

Notably, the ICC's opening of a preliminary examination and the prospect of prosecution influenced key actors' decision making. For instance, President Camara's shooting on 3 December 2009 by his Presidential Security Officer Lt. Aboubacar "Toumba" Diakité was caused over rumours that he would be forced to take the blame in front of the ICC for the 28 September 2009 events. ${ }^{79}$

When the OHCHR was established in Guinea in June 2010, it encountered a country that has not cooperated with human rights mechanisms or followed international standards of justice and accountability. ${ }^{80}$ The Country Office witnessed a complete lack of judicial independence, limited government support for accountability despite the promising rhetoric of President Conde, key suspects in government posts (e.g. Moussa Tiegboro Camara and Claude Paci) that enabled them to influence investigations, insufficient protection of the rights of the accused and a lack of a framework for protection and support for witnesses and victims.

The OHCHR has provided technical support to the newly established Ministry of Human Rights and Civil Liberties and assisted the reforms on human rights protection for the National Reconciliation Commission. ${ }^{81}$ The Office played a crucial role in integrating international human rights law provisions in the Guinean criminal legislation reform, throughout its participation

77 The Office of the Prosecutor, 'Report on Preliminary Examination Activities 2018', International Criminal Court, pp. 46.

78 Ibid., pp. 48.

79 ввС, "Guinea aide admits shooting junta leader Camara", BBC News, 19 December 20o9, available at http://news.bbc.co.uk/1/hi/8415659.stm.

8o Interview with the Head of the онс нR Guinea Office, Mr Louis Marie Bouaka, January 2018.

81 Elise Keppler, 'Waiting for Justice: Accountability before Guinea's Courts for the September 28, 2009 Stadium Massacre, Rapes, and Other Abuses', HRW, pp. 52. 
in the law and codes reform committee. As a result, torture has been defined and criminalized in the Guinean legal framework and legal gaps relating to the prosecution of gender-based violence were addressed. Tribunals of first instance were granted jurisdiction to prosecute criminal cases with the possibility of second hearing. Additionally, the Guinean Parliament withdrew the death penalty in the new criminal law of 2016.

Following OHCHR's technical support, the National Assembly adopted amended its penal laws and defined torture in accordance with the UN Convention on Torture and Other Cruel, Inhuman or Degrading Treatment or Punishment. ${ }^{82}$ Similarly, OHCHR contributed to the preparatory activities of the review of the criminal law procedure to ensure that the amended law will comply with international human rights standards.

The definition of crimes against humanity, as detailed in the Rome Statute of the ICC, is now also integrated into Guinean law, as a result of the OHCHR's work. ${ }^{83}$ The Country Office further assisted the Ministry of Justice to integrate the new Criminal Code in the work of magistrates and military judicial officers, as well as professionals of the penal chain (Judicial Police Officers, magistrates, clerks and prison staff) in the four regions of the country. The Office was also involved in the development of the National Strategy of Priority Actions for the implementation of security and justice sector reforms. ${ }^{84}$

Furthermore, OHCHR provided training to managers from the former Ministry of Human Rights and Public Liberty on human rights monitoring. The former Ministry was replaced by the Ministry of National Unity and Citizenship which is currently in charge of human rights. ${ }^{85}$ While онснR Guinea has continued to monitor and report human rights violations cases in the country since it was established, the importance of national monitoring cannot be overstated. Likewise, coordination with the other external assistance efforts or cooperation with other partners remains key in order to mainstream human rights in every level of strategic planning and to effectively cover all regions of the country.

Another positive result linked to the work of the онснR Country Office relates to ensuring government's reporting to treaty bodies, which has not been

82 The former penal code adopted in 1998 considered torture only as an aggravating circumstance causing harm to people.

83 Interview with Head of the онCHR Guinea Office, January 2018.

84 Interview with the Director of the Africa Branch онснR Geneva, January 2018.

85 OHCHR carried out two workshops in Conakry for the National Independent Human Rights Institution on human rights monitoring and reporting, and transitional justice mechanisms. 
the case for many years since Guinea had 15 overdue reports to five UN treaty bodies pending when the Country Office was established. OHCHR Guinea supported the transitional Justice Process in Guinea by providing advice and training to the members of the Prime Minister's Office and the working group on reconciliation on human rights law and transitional justice. Hence, OHCHR succeeded in changing the vision of key actors in charge of conducting the reconciliation process. This allowed the setting up by the Prime Minister of a working group in charge of reconciliation and the elaboration of a draft law establishing a truth and reconciliation commission in Guinea (CONARGUI) in accordance with international standards. The draft law was validated during a national workshop in April 2017 and was sent to the Government by The Prime Minister's Office in May 2017. During the whole process, the Office ensured the integration of a gender perspective at all stages, from the drafting of the CONARgui I \& II Project to the designing of national consultations tools, the conduct of national consultations and the drafting of the final report of the national consultations.

With the UN's support, the government established an inter-ministerial Committee of Human Rights on 21 July 2014, responsible for drafting reports to Human Rights Mechanisms. In 2014 and 2017, OHCHR's Guinea Office provided training and technical support to the Committee and members of civil society organizations. ${ }^{86}$

Regarding the Universal Periodic Review (UPR), Guinea was reviewed in the framework of the UPR mechanism in 2010 and 2015. The Country Office has provided technical support both to the Government, UNCT and civil society organizations (csos) in submitting their respective reports and in the follow up of the recommendations. The country has prepared and submitted

The National Human Rights Institution was set up in December 2015. Report of action points from the OHCHR Guinea Office, January 2018.

86 Guinea produced its first report on torture in 2014 and on the Protection of the Rights of All Migrant Workers and Members of their Families in 2015. In 2017, онснR Guinea provided training and technical support to the National Inter-Ministry Committee of Human Rights which led to the submissions of the State complementary reports on the implementation of CRC-OP-AC (Optional Protocol to the Convention on the Rights of the Child on the involvement of children in armed conflict) and CRC-OP-SC (Optional Protocol to the Convention on the Rights of the Child on the sale of children child prostitution and child pornography), as well as the periodic report on the International Covenant on Civil and Political Rights to the Human Rights Committee and the Committee against Torture. The same support was provided to civil society organizations for their alternative reports on CRC-OP-AC and CRC-OP-SC. 
reports to the first and second round of the UPR sessions, with most of the recommendations being completed and implemented with the support of OHCHR.

The OHCHR Guinea also provides support to the implementation of the security and justice sector reform to strengthening the national justice system that functioned in accordance with human rights law. This is where regular field monitoring and visits increase security forces' compliance with international human rights standards. ${ }^{87} \mathrm{OHCHR}$ Guinea continues to monitor detention facilities and provide technical advice to judicial actors that resulted in improved management of cases of defendants and also permitted advocacy for improvement of conditions of detention. Throughout the monitoring of trials, OHCHR improved compliance of court proceedings and decision-making processes regarding international human rights law. ${ }^{88}$ OHC HR Guinea provides technical advice and trainings to law enforcement officials and engages in advocacy towards accountability for human rights violations committed by defence and security forces.

In addition to frequent consultations with authorities, OHCHR has established, since 2014, four committees tasked to follow up cases of human rights violations in Conakry, Nzérékoré, Faranah and Kankan. Representatives of the police, the army, the gendarmerie, the ministry of justice and human rights organizations participate in monthly meetings on a regular basis. This is a good opportunity to share cases of human rights violations, report to relevant authorities and ensure that adequate measures are taken. An important development in this sense was that OHCHR Guinea Office set up quarterly meetings with the Diplomatic Corps in Guinea, and monthly meetings with human rights NGOs. These meetings constitute a framework of information sharing on human rights violations as well as advocacy on some specific issues. ${ }^{89}$

The UN also supported the establishment of a national Truth, Justice and Reconciliation Commission, as well as a National Human Rights Commission. The Peacebuilding Support Office (PBSO) focused mostly on the national consultations as well as the so-called infrastructures sociales de paix (translated as social peace infrastructures). However, the process on the creation of the

87 This point was made during discussions on what the онснR Guinea has done towards ensuring that security forces in Guinea comply with the new laws and human rights standards. Interview with Director of the Africa Branch of онCHR Geneva, January 2018.

Written correspondence with the Director of the Africa Branch of онснR Geneva, January 2018.

89 Interview with Head of the онс HR Guinea Office, January 2018. 
Truth and Reconciliation Commission is currently stalled (after the end of the consultation process). The infrastructures sociales de paix are currently under review and will be part of a larger national system on conflict prevention that is led by the Guinean Ministry of National Unity. Part of creating the system was a conflict analysis workshop that was organized in 2017 in Conakry with the support from a UN Diplomacy Prevention Action (DPA) and UNDP Joint Programme, together with the Peace Building Fund (PBF).

\section{$5 \quad$ Peacebuilding}

In $2010^{90}$ and $2011,{ }^{91}$ the Guinean government sent two requests to the Peacebuilding Commission (РвC) asking to be placed on its agenda. Guinea was the first country ever to request to be put on the PBC agenda. On 2 March 2011, following consultations with Guinean government representatives, the President of the Рвс accepted Guinea's request considering that although Guinea did not experience a civil war, "it had all the ingredient for one". ${ }^{92}$ The РВC's support for Guinea centred around three main priorities: youth and women employment, security sector reform, and promotion of reconciliation and national unity. ${ }^{93}$ Indeed, the PBC-Guinea configuration's focus on the promotion of national reconciliation and unity, acknowledged the deep effects of "several decades of authoritarian rule and military dictatorship which has left a legacy of fractured civilian-military relationships, a population that has lost all confidence in those that govern it, gross human rights violations and deep

9o Ministre d'Etat Charge des Affaires Etrangeres, de l'Integration Africaine et de la Francophonie, 'No. 510/MEAEIAf/CAB/CP/10', Republique de Guinee, 21 October 2010, available at https://www.un.org/peacebuilding/sites/www.un.org.peacebuilding/files/ documents/govt_request_first.pdf.

91 Mission Permanente de la Republique de Guinee Aupres de l'Organisation des Nations Unies, 'No. $079 / \mathrm{MPg} / \mathrm{NY} / \mathrm{Amb} / \mathrm{asd} / 11$ : Note verbale', Mission Permanente de la Republique de Guinee Aupres de l'Organisation des Nations Unies 25 January 2011, available at https://www. un.org/peacebuilding/sites/www.un.org.peacebuilding/files/documents/govt_request_ second.pdf.

92 Author's interview.

93 UN Peacebuilding Commission, 'Note from the Chairperson', United Nations, 2 March 2o11, available at https://www.un.org/peacebuilding/sites/www.un.org.peacebuilding/files/ documents/pbc_response_govt.pdf; UN General Assembly and Security Council, Statement of mutual commitments on peacebuilding in Guinea between the Government of Guinea and the Peacebuilding Commission, UN Doc Pвс/5/GUI/2, 23 September 2011. 
inter-ethnic rivalry", ${ }^{4}$ along with the problem of the political instrumentalization of ethnic identity. ${ }^{95}$

These three priority areas remained unchanged ${ }^{96}$ until PBC officially terminated the configuration on Guinea in July 2017. The PBC branch and the Peacebuilding Support Office (PBSO) are currently looking into the possibility of engaging the PBC in a more flexible form in Guinea, ${ }^{97}$ which should indeed be encouraged given the important work that the PBso has done in these three main priority areas so far.

As per the COI recommendations, the Guinean authorities established a national Panel of Judges to investigate and prosecute alleged crimes related to these events. Despite the CoI findings, the initial domestic inquiry backed by the ruling junta in early 2010 found that the number of deaths in the stadium massacre was almost three time less than what the cor reported, and found that Camara was not responsible for the 2009 massacre, blaming solely Lt Aboubakar Toumba Diakite instead. ${ }^{98}$

The 2010 constitution mandated the establishment of an independent national human rights institution in charge of promoting and protecting human rights, as well as monitoring and reporting on ongoing human rights violations and acting as an early warning system and a platform for strengthening the human rights discourse in the country. ${ }^{99}$ In March 2011, President Condé established by decree the National Human Rights Commission. ${ }^{100}$ In

94 Ibid., para. 12-18.

95 UN Peacebuilding Commission, 'Report of the Mission to Guinea 11 to 15 March 2012', United Nations, 15 March 2012, available at https://www.un.org/peacebuilding/sites/www.un.org. peacebuilding/files/documents/pbc-gui_visit_march_2012_-_report_en_version.pdf, para. 11 .

96 See the UN Peacebuilding Commission reports: UN Doc PBC/6/GUi/2 (8 June 2012), UN Doc PbC/6/GUI/3 (19 June 2012), UN Doc PBC/8/GUI/1 (12 August 2014) and UN Doc PBC/8/GUI/2 (12 November 2014). The PвC Guinea configuration website has not been updated since 2015 .

97 Email correspondence with new contact point for Guinea in the PBSO, January 2018.

98 ввс, "Guinea junta blames Toumba Diakite for massacre", BBC News, 2 February 2010, available at http://news.bbc.co.uk/1/hi/world/africa/8493875.stm (accessed 25 November 2017); France 24. 2010. "Guinea absolves Dadis Camara of any blame for massacre", France 24, 2 February 2010, available at http://www.france24.com/ en/20100202-guinea-absolves-dadis-camara-blame-massacre.

99 Articles 146-148 of Guinea's National Constitution, promulgated on 19 April 2010.

100 Guineenews, "Décrets: Alpha Condé crée une Commission Nationale des Droits de l'Homme", Guineenews, 18 March 2011, available at http://www.guineenews.org/articles/ detail.asp?num=201131813928. 
November 2011, the Government and the UN signed a Joint Communiqué focused on tackling sexual violence, and specifically to: "(i) combat impunity for sexual violence; (ii) implement the recommendations of the cor; (iii) reinforce security sector reform with a view to including prevention of sexual violence; (iv) engage in a dialogue with the victims of the 28 September 2009 events, including victims of sexual violence; and (v) ensure reparations and promotion of national reconciliation".101

In 2012, Lt. Col. Moussa Tiegboro Camara (the former CNDD minister in charge of the Fight against Drug Trafficking and Organized Crime) and Col. Abdoulaye Chérif Diaby (the former Health minister) were both indicted by a Guinean court, followed by the indictment of former Conakry Governor, Major Sékou Rosco Camara, in February 2013. ${ }^{102}$ Judicial cooperation with neighbouring countries has recently increased, and this led to further arrests of key suspects, including that of Lieutenant Aboubacar Sidiki Diakité, "aidede-camp" of former President Camara. ${ }^{103}$

Since 2012, the Team of Experts in New York has provided technical assistance to the Panel of Judges on strengthening the rule of law. Through the Team of Experts, and in line with the Joint Communiqué in December 2012, the Office of the SRSG-SVC deployed an expert to provide technical assistance to the Panel of Judges. In particular, the deployed senior judicial advisors worked with the Guinean judges on the following key aspects: strengthening investigation techniques, collecting and safeguarding testimonies and evidence from survivors and establishing a regular dialogue between the Ministry of Justice, civil society organizations and victims' groups. ${ }^{104}$

The domestic investigation - which began in February 2010 - broke new ground in combatting impunity in the country, but progressed slowly amid political, financial, and logistical obstacles. During the investigation, the

101 Office of the Special Representative of the Secretary General on Sexual Violence in Conflict. 'Annual Report 2011: Team of Experts: Rule of Law/Sexual Violence in Conflicts', Stop Rape Now, pp. 26.

102 Mohamed Saliou Camara, 'Political Crisis and Ecowas-Mediated Transition in Guinea', Stichproben. Wiener Zeitschrift für kritische Afrikastudien, Vol. 16, issue 3o/2016, 2016, pp.21. Office of the Special Representative of the Secretary General on Sexual Violence in Conflict. 'Annual Report 2011: Team of Experts: Rule of Law/Sexual Violence in Conflicts', Stop Rape Now, pp. 27.

Interview with human rights officer from онснR who is a member of the Team of Experts: Rule of Law - Sexual Violence in Conflict division, January 2018. She mentioned that Mr. Ahmedou Tidjane Bal (former Minister of Justice and President of the Supreme Court of Mauritania) has been deployed as the senior judicial advisor to Guinea to provide support to the Panel of Judges in charge of investigating the crimes of 28 September 2009, as well as to the Ministry of Justice. 
judges have brought charges against high-ranking members of the security forces, whose trials were scheduled to start first in 2018, then in 2019. Over the course of these years, The Panel of Judges heard testimonies from over $45^{\circ}$ victims and their families, including the testimony of at least 200 victims and witnesses of sexual violence. In December 2017, 9 years after the massacre, and 7 years since the start of the national investigation, 13 high-ranking military officials were indicted, including former and current high-level officials, such as Moussa Dadis Camara and his vice-president Mamadouba Toto Camara. ${ }^{105}$

Guinean authorities also asked the UN Team of Experts to support the Minister of Justice in creating a Coordination Committee to prepare the next trials for the 28 September 2009 massacre. The technical assistance has focused on witness and victims' protection, and outreach to Government officials, survivors, and the public. The UN Team of Experts will provide such support until all trials are finalized. ${ }^{106}$ This is an important undertaking given the potentially positive message it could carry to exemplify what successful atrocity prevention entails, in both early stages and with a powerful deterrence effect. The incremental process of combatting impunity for international crimes (such as crimes against humanity) in Guinea emphasizes a national judicial process, but with technical support from the international community.

The ICC, which opened its preliminary examination in October 2009, has repeatedly urged the Guinean authorities to progress in their investigation. But since the ICC is a court of last resort, it can only act when national courts are unable or unwilling to investigate and prosecute cases under its authority. The long-awaited conclusion of the September 28, 2009 investigation gave hope that accountability for the atrocity crimes committed in September 2009 could be delivered in Guinea, through its domestic justice system. Delivering justice for one of Guinea's worst episodes of political violence and atrocity crimes to date would mark the government's willingness and capability to end impunity for the security forces, to demonstrate the independence of the judiciary, and to improve the rule of law. However, it is paramount to ensure that the Guinean courts do indeed have the necessary resources to proceed with fair trials and suitable protection and security for those involved.

There was some progress since December 2017, with several steps forward that looked more promising. In April 2018, the Guinean Minister of Justice,

105 HRW, 'Guinea: Judges Conclude 2009 Massacre Inquiry', $H R W$, 10 November 2017, available at https://www.hrw.org/news/2017/11/10/guinea-judges-conclude-2009-massacre-inquiry.

106 Office of the Special Representative of the Secretary General on Sexual Violence in Conflict. 'Annual Report 2011: Team of Experts: Rule of Law/Sexual Violence in Conflicts', Stop Rape Now, pp. 29. 
Cheick Sako, appointed a steering committee to organize the trial, and yet the committee has only met sporadically and failed to set a trial date. In October 2018, Cheick Sako announced that a location had been chosen (a movie theatre near the capital) and a provisional budget was drafted for the trial, with Guinea expected to cover $77 \%$ of the total cost (estimated at more than 8.5 million US dollars) and international contributions for the remainder of the funding. ${ }^{107}$ However, Cheick Sako's recent resignation has triggered concerns of further delays in the stadium massacre trial, with Guinean human rights groups now "worry[ing] that with Sako gone, any remaining momentum for the trial will be lost."108

To add further complexity to an already complex context, as important as these steps are, a commitment to creating a culture of accountability and respect for human rights would also require investigating past abuses, predating the 2009 massacre. The lack of reconciliation or transitional justice processes following the atrocities committed during former regimes remains staggering. Such a process should start with Sekou Touré's 26-year reign that "created a legacy of distrust and fear for those attempting to call their government to account". This would also be needed to investigate "the dynamics that gave rise to and sustained successive authoritarian and abusive regimes", in order to shed light on the ethnic dimension of these crimes. ${ }^{109}$

\section{7}

\section{Elections}

President Camara's dismissal of the National Assembly following his coup in 2008 effectively left the country without a functional and representative parliament. At the beginning of 2010, Sekouba Konaté's transitional government established the National Transition Council (CNT), an ad hoc (thus not fully functional, and unrepresentative) legislative body. It was only then that the issuing of recommendations on institutional reforms and legislation drafting

\footnotetext{
107 Shannon Walker, "Guinea government announces progress toward trial of stadium massacre suspects", Jurist, 22 October 2018, available at https://www.jurist.org/news/2018/10/ guinea-government-announces-progress-toward-trial-of-stadium-massacre-suspects/. Trial', HRW, 31 May 2019, available at https://www.hrw.org/news/2019/o5/31/ resignation-confirms-fears-delay-guinea-stadium-massacre-trial.

109 Corrine Dufka, “We Have Lived in Darkness": A Human Rights Agenda for Guinea's New Government', $H R W$, pp. 31.
} 
were made possible. ${ }^{110}$ The 2010 Ouagadougou Peace Agreement ${ }^{111}$ included a return of order and civilian rule and the organization of elections. The importance of the 2010 presidential elections cannot be underestimated. The elections marked a historic moment, since there was no incumbent, which was a first in Guinean history since its 1958 independence. ${ }^{112}$ Another first was that the elections were organized by an election commission, the National Independent Electoral Commission (CENI).

The presidential elections were prepared by Konatés transitional government. In preparation for the presidential elections, the new transitional national legislature adopted a new constitution on April 19th 2010 and a new electoral code (which also established CENI). Over 20 candidates participated in the presidential election, which was delayed three consecutive times due to fraud allegations and technical difficulties. ${ }^{113}$ Although the first round of the elections was generally peaceful, in the run-off interethnic clashes between Fulani supporters of UFDG candidate Cellou Dallin Diallo and Malinke supporters of RPG candidate Alpha Condé escalated in the capital, resulting in over 2,00o people being displaced at the end of October 2010 alone. ${ }^{114}$

On 14 November, Alpha Condé, the Malinke backed leader, gained $52 \%$ of the votes in the presidential run-off. Until the Guinean Supreme Court certified the result on December 21st 2010, when Alpha Condé was declared President, ethnic tensions and clashes escalated throughout the country leading to reports of injuries at the hands of the security forces. ${ }^{115}$ Alpha Condé was elected for another presidential term in 2015. ${ }^{116}$

The parliamentary elections, which were eventually held on gth September 2013, were subject to numerous and long delays too, and also to opposition

\footnotetext{
$110 \quad$ Ibid., p. 65.

11 UN Peacemaker, 'Ouagadougou Joint Declaration', UN Peacemaker.

112 The Carter Center, 'Observing the 2010 Presidential Elections in Guinea: Final Report', The Carter Center, pp. 8.

113 Global Centre for the Responsibility to Protect, 'Statement on the Situation in Guinea, November 2010', Global Centre for the Responsibility to Protect, 4 November 2010, available at https://www.globalr2p.org/publications/statement-on-the-situation-inguinea-november-2010/.

114 Ibid.

115 BвC, "Alpha Conde declared winner in Guinea president polls", BBC News, 15 November 2010, available at https://www.bbc.com/news/world-africa-11762142.

116 Agence France-Presse, 'Guinea president Alpha Condé wins second term with clear majority', The Guardian, 17 October 2017, available at https://www.theguardian.com/ world/2015/oct/17/guinea-president-alpha-conde-election.
} 
boycotts, strict government control and low voter participation. ${ }^{117}$ Before 2013, the last legislative elections were organised in 2002.

The politicization of ethnicity has played an important role in Guinean politics, especially after the 2010 presidential elections - the main parties and administrative regions being patterned along ethnic lines. Historically, the Malinke ethnic group has dominated politics, with Sekou Touré actively excluding other ethnicities from his government. ${ }^{118}$ Marginalisation of, and repression against, ethnic groups since 1958 has contributed to over one third of Guinea's population emigrating to other countries. ${ }^{119}$ For instance, the Fulbe (also known as Peuhl) plot of 1976-77, which led to the imprisonment and execution of numerous Peuhl ethnic intellectuals, led to a mass exodus of Peuhl ethnics and "a painful legacy of mistrust between the Peuhl" and the Malinke ethnic group, which is the second largest in the country.120

Following the Ouagadougou Declaration in January 2010, EcowAs, the AU and the UN presented the Guinean government with a security sector operational roadmap. ${ }^{121}$ This roadmap aimed to subject security forces to civilian oversight, ensure fiscal transparency, and reduce the size of the army. ${ }^{122}$ The plan was met with suspicion from both soldiers (who prefer to see reforms in terms of their materials resources and logistics) and those suspicious of civilian oversight in general. ${ }^{123}$

Security sector reform has been one of the three key priorities of the Peacebuilding Commission in Guinea. ${ }^{24}$ The PBC supported the Guinean government in creating a roadmap for security and defence reform and closely monitoring security sector reforms. This included the planning and

\footnotetext{
117 Corrine Dufka, “We Have Lived in Darkness": A Human Rights Agenda for Guinea's New Government', $H R W$, pp. 65 .

118 Alieu Darboe, 'Guinea: 1958-Present: Summary of events related to the use or impact of civil resistance', International Center on Nonviolent Conflict, pp. 4.

119 Ibid.

120 Corrine Dufka, "We Have Lived in Darkness": A Human Rights Agenda for Guinea's New Government', $H R W$, pp. 11.

121 UN Office for West Africa, 'Joint Press Release: EcowAS-AU-UN- Guinea: Security Sector Reform', UNOWA, 4 May 2010, available at JOINT PRESS RELEASE ECOWAS-AU-UN Guinea: Security Sector Reform | UnOwA (unmissions.org); UN General Assembly and Security Council, Statement of mutual commitments on peacebuilding in Guinea between the Government of Guinea and the Peacebuilding Commission, para. 20. Corrine Dufka, “'We Have Lived in Darkness": A Human Rights Agenda for Guinea's New Government', $H R W$, pp. 55 .

123 Ibid., p. 55 .

124 Ibid., para. 43-44.
} 
retirement preparations for military personnel, ${ }^{125}$ and thus the establishment of a Minister for Veterans, separate from the Minister of Defence. ${ }^{126}$ With the support of the Peace Building Fund (PBF), the OHCHR Country Office contributed toward the Code of Conduct of Defence based on human rights, edited 35,00o copies of the Code, and also supported the Ministry of Defense in implementing the new provisions within the military barracks of the five military regions. The UN Guinea Office also developed a human rights training programme for the Defense and Security Forces and edited Human Rights modules for DSF training centers. Its training sessions targeted members of DSF in Kindia and Kankan in December 2017; and set up a pool of forty trainers from DSF. ${ }^{127}$ However, according to the OHCHR Country Office, an urgent need remains to provide further training and coaching in all the military, police and gendarmerie training schools and centers to ensure the effective integration and teaching of these HR modules. ${ }^{128}$

Apart from the revision of key legal texts, including the Code of Criminal Procedure, another meaningful component of the 2015-2019 judicial reform plan included the establishment of a Military Tribunal. This proved to be a very effective undertaking since military officers and security forces had become much more careful after realizing they could be prosecuted anytime. ${ }^{129}$

Also important, the Country Office supported the establishment of the Codes of Ethics and Discipline of the National Police and Civilian Protection. During the outreach activities, the Office distributed more than 6,050 materials, including pamphlets, posters, booklets, human rights facts-sheets, extracts from human rights documents and copies of trainers' materials. Furthermore, the OHCHR organized training sessions for DSF on civilian and democratic control of the defense and security forces with the support of the PBF. The training focused on the obedience of DSF to legally established civilian authorities. ${ }^{130}$

Furthermore, since 2013, OHCHR-Guinea in collaboration with the International Committee of Red Cross and the Ministry of Defence also carried

125 UN Peacebuilding Commission, 'Report of the Mission to Guinea 11 to 15 March 2012', United Nations, para. 13 .

126 UN Peacebuilding Commission, 'Report of the visit of the Chair of the PвC Guinea Configuration to Conakry (31 May to 2 June 2015)', United Nations, 1 April 2015, available at https://www.un.org/peacebuilding/sites/www.un.org.peacebuilding/files/documents/ visit_guinea_june_2015-report_en.pdf, pp. 4-5.

Written correspondence with the Director of the Africa Branch of онсHR Geneva, January 2018.

128 Author's interview with the head of о нс нR Country Office, January 2018.

129 Ibid.

130 Written correspondence with the Director of the Africa Branch oHCHR Geneva, January 2018. 
out annual sessions of pre-deployment training and sensitization for militaries of the standby battalion to be deployed in the MINUSMA peacekeeping mission in Mali in the Samoreya military camp of Kindia. This training reinforced respect of international humanitarian law, human rights and civilian protection for participants in the peacekeeping mission to Mali.

This article identified a taxonomy of measures, taken by a variety of international, regional, sub-regional and local stakeholders, in different combinations, which ended up reducing the risk of atrocity crimes reoccurring after the 2009 stadium massacre. The measures were varied and encompassed: preventive diplomacy, targeted sanctions, justice and security sector reforms, and included measures aimed at combating impunity and strengthening accountability and the rule of law. The effectiveness of all these measures, taken together, was facilitated by the already existing diplomatic links and by the African-led institutional framework that was put in place after the 2008 coup.

The uniqueness of the Guinean context relates to the fact that atrocities were not perpetrated by populations at large - as has been the case elsewhere on the continent, such as in Rwanda, DRC, or in Bosnia. Instead, the Defence and Security Forces (DSF) were the only perpetrators. This explains why external assistance (both international, from the $\mathrm{UN}$, and regional and sub-regional) as well as all prevention efforts focused on institutional and legislative reforms of the security and justice sectors.

Ethnicity has played an important role in Guinean politics, with both parties and administrative regions being patterned along ethnic lines. As witnessed multiple times in Guinea and elsewhere, violence escalates around election times. As such, the obvious trend in Guinea that ethnic tensions often turn deadly around election time should be one of the red flags informing all early atrocity prevention mechanisms. Elections have sparked incidents of ethnic violence and security forces abuses, but all post-20og incidents so far have not escalated to the atrocity levels seen in the 2009 stadium massacre.

Importantly, Guinea is not a typical example in terms of atrocity and conflict prevention, given the unique regional and global dynamics that allowed for a rapid and rather coherent response to the September 2009 stadium massacre and the subsequent departure of Moussa Dadis Camara. Willing regional partners together with the US and France's engagement triggered the creation of the UN Commission of Inquiry following the massacre. Furthermore, Camara's aide-de-camp's attempt to assassinate him also provided all external 
and internal actors involved with a unique window of opportunity to transition to civilian rule, which would otherwise not have appeared. President Compaore and his appointment of Sekouba Konaté as the head of transition, who then in turn agreed to organize elections, facilitated this context further and proved significant to longer-term prevention.

These elements aligned perfectly to provide a unique context in Guinea, but the UN's contributions were a key component in the mixture. The UN enabled the taxonomy of preventive measures to work by assisting the key actors involved in diplomatic mediation and ensuring policy consensus throughout the process. A reassessment of priority areas going forward after the February 2018 local elections, and of achievements so far is necessary. While the PBC officially terminated the configuration on Guinea in July 2017, further PBSO and $\mathrm{PBC}$ engagement in Guinea is highly desirable, given the multiple reform delays encountered after the start of the Ebola crisis in 2014 and the amount of reforms still to be implemented. Suggestions for further potential PBC engagement include focusing on three areas for progress in the country: safety and security, the processes of reconciliation and justice, and the private sector. ${ }^{131}$

The case of Guinea provides several important lessons, which should inform atrocity crime prevention efforts elsewhere, with the caveat of acknowledging the particularities at play in this context. In turn, these lessons in effective atrocity prevention inform the specific preventative mechanisms that are encompassed within the broader Responsibility to Protect $\left(\mathrm{R}_{2} \mathrm{P}\right)$ agenda. The latter include various prescriptions for a variety of actors in charge of acting to prevent atrocities, while showing respect for both state sovereignty and human rights at the same time. ${ }^{132}$

First, while the combination of international and regional efforts in Guinea could point to a successful atrocity prevention story, the uniqueness of the context merits its own assessment and reminds us of the difficulty of replicating the exact combination of atrocity prevention efforts elsewhere. The particularities are important: the crimes were committed by security forces only; Guinea has been the only country to request to be added to $\mathrm{PBC}$ agenda without a UNSC referral; the lack of a political or peacekeeping mission; already existing international-regional-national coordination (ICG-G) prior to 2009 stadium massacre; and the shifts in leadership facilitating the transition to civilian rule, Security and Human Rights (London: Routledge, 2011).; and Cristina G. Badescu. 2009. "'The Responsibility to Protect": Embracing Sovereignty and Human Rights', in Noha Shawki and Michaelene Cox (eds.), Negotiating Sovereignty and Human Rights: Actors and Issues in Contemporary Human Rights Politics (Farnham: Ashgate, 2009), pp. 81-98. 
with Gen. Sekouba Konate's appointment as interim leader creating an unexpected window of opportunity for preventive diplomacy.

It is thus noteworthy that preventive diplomacy and monitoring activities need to be tailored to each individual case. Furthermore, when assessing the common risk factors from the UN Office's Framework of Analysis, an additional assessment differentiating between structural risk factors, inhibitors (absence of mitigating factors), and potential triggers (occurring at later stages) - alongside a "temporal" taxonomy - might be helpful.

Second, partnership between international and regional/sub-regional organizations is key in delivering atrocity prevention. Following the 2008 coup, ECOWAS and AU, supported by the UN, were already engaging with the Guinean government and continued to do so, while closely monitoring the situation on the ground after the 2009 stadium massacre. Such consolidated efforts paid off: Blaise Compaore, the EcowAS appointed mediator, Ibrahima Fall from Senegal, the AU's Special Envoy, and Said Djinnit, the UN Special Representative for West Africa, also a seasoned AU diplomat with deep knowledge of AU's decision-making process, engaged successfully in shuttle diplomacy and in finding a political solution. The ICG-G facilitated the coordination amongst these actors in order to produce one coherent mediation track (which translated into speaking with "one voice"). Arguably, such coordination was possible because no actor involved in the coordinated response has had any particular national interests in Guinea.

Third, and related to this, regional and sub-regional efforts confer domestic legitimacy to atrocity prevention processes. However, this is not sufficient: sustained external support is absolutely essential in the African context. EcowAs's early intervention in Guinea is the perfect illustration of its strength in providing a diplomatic response to coups and other unconstitutional attempts to grasp power. At the same time, adequate financial packages to fund the collaborative, agreed responses (PBF) and expertise (OHCHR) were paramount. OHCHR in particular played a key role in assisting the government with its reforms. In terms of ensuring accountability, the ICC's search for updates on the status of national proceedings and assessment of the progress in Guinea towards organizing a trial within a reasonable time frame proved key towards ensuring action at national level.

With security sector reform being an essential atrocity prevention tool in cases like Guinea, long-term engagement on the part of the UN is much needed. Deferral to regional/sub-regional organizations that lack capacity and will is not an option. It was in this context that the UN's focus on local, regional particularities proved particularly helpful. Appointing an UNOWA Special Representative with high authority in the region (Said Djinnit) was extremely 
important throughout mediation. OHCHR played a key role, especially after setting up the OсHHR Office in Guinea in regards to the strengthening of reform for human rights protection and the judicial reform.

Fourth, prompt calls for accountability do deter the commission of atrocity crimes. As such, the importance of tackling the culture of impunity in Guinea and the focus on accountability cannot be overstated. Guinea has had a long record of serious violations of international human rights, and, in particular, it has developed a pattern of extreme use of violence by security forces to repress dissent. The Guinean judicial system, with its inadequate resources, high levels of corruption and dependence on the executive branch, has historically failed to hold accountable those responsible for human rights violations, and especially members of the security forces. The онсHR called for an independent inquiry two days after the stadium massacre, the COI assessed that crimes against humanity were committed, the ICC warned against violence escalation, and candidates were told to refrain from inciting violence. Junta leaders were afraid of ICC indictments (see Diakrite's shooting of Camara) and the international and regional actors' repeated references to accountability made individuals considering perpetrating crimes aware and afraid that they could be held accountable internationally.

Fifth, smart sanctions worked in Guinea in terms of preventing atrocity crimes (as opposed to the comprehensive sanctions of the 199os). Smart sanctions target "painful" effects on specific members of the regime, particularly on elites. Travel restrictions in particular proved very efficient. For example, sanctions on Sekouba Konate, the deputy leader of the junta at the time of the massacre, contributed to him engaging in mediation efforts in order to have his name removed from the EU sanctions list.

Sixth, and also related to the point above, Guinea illustrates how the UN Security Council does not have to have a role in atrocity prevention for $\mathrm{R}_{2} \mathrm{P}$ and its preventive implementation to work. Imposed sanctions worked without coming from the UNSC, which never added Guinea to its agenda. Furthermore, OHCHR, PBC and UNDP were involved in assisting with the implementation of Pillar 1 and 2 of $\mathrm{R}_{2} \mathrm{P}$ without the help or backing of the UNSC.

\section{Biography}

Dr. Cristina G. Stefan is the Founding Director and current Co-Director of the European Centre for the Responsibility to Protect. She has also launched the Women Network on the Responsibility to Protect, Peace and Security, a network of global women working towards international peace, security 
and furthering $\mathrm{R}_{2} \mathrm{P}$. She has a wide range of research interests including the Responsibility to Protect $\left(\mathrm{R}_{2} \mathrm{P}\right)$, international relations theory (Constructivism and Norm Studies), international security, peace and conflict studies, women, peace and security (WPS), and human protection. She has a PhD and M.A in International Relations from Western University Canada. 